\title{
CHRZEŚCIJANIE W OTOCZENIU SZACHA. PROBLEM INKULTURACJI NA PODSTAWIE USTAWODAWSTWA SYNODALNEGO KOŚCIOLA ORIENTALNEGO PRZEŁOMU V I VI WIEKU
}

Zagadnienie akomodacji zawsze budziło w Kościele dużo kontrowersji. $\mathrm{Z}$ jednej strony większość uczestników dyskusji nie ma wątpliwości, że przekaz ewangeliczny winien być niezależny od czynników kulturowych czy politycznych, $z$ drugiej strony wyznaczenie granicy pomiędzy tym, co istotne i zasadnicze a tym, co stanowi jedynie ludzki dodatek, nie jest łatwe w praktyce.

Szczególnie skrajne sytuacje ogniskują dyskusję i zmuszają do odpowiedzi na zasadnicze pytania. Dyskusja jest tym bardziej gorąca, gdy dotyka życia codziennego, wkraczając głęboko w to, co dziś nazywamy prywatnością każdego z nas. Taką kwestią jest między innymi zagadnienie celibatu, dopuszczalności święcenia żonatych mężczyzn, zawierania małżeństw przez już wyświęconych czy kwestii wymagań stawianych w tym względzie wobec kandydatów do urzędów kościelnych. Zagadnienie to na przestrzeni wieków rodziło wiele kontrowersji, a argumenty i racje teologiczne przeplatały się z ludzkimi emocjami i osobistymi wyborami. Decyzje, jakie podejmowała wspólnota wierzących, podlegały zmianie i trudno mówić o jednorodności postaw w tej kwestii czy też o osiagniętym kompromisie. Na przełomie wieku V i VI w Asyryjskim Kościele Wschodu zagadnienie to stało się centralnym dla zwoływanych wtedy synodów których rozstrzygnięcia do dziś wywołują konsternację u wielu badaczy, nie tylko we wspólnotach, gdzie dopuszczalne jest święcenie wyłącznie celibatariuszy. Chodziło bowiem nie tylko o zgodę na święcenie żonatych, ale także - wbrew całej tradycji Kościoła - o zgodę na zawarcie związków małżeńskich dla już wyświęconych duchownych, w tym także dla biskupów, z patriarchą włącznie.

1. Kontekst historyczny. Na wstępie należy podkreślić dwie kwestie. Zachowane przekazy są na tyle niejasne, że nie pozwalają na precyzyjne ustalenie, co skłoniło biskupów orientalnych do podjęcia decyzji stojących w całkowitej

\footnotetext{
${ }^{*}$ Ks. dr hab. Jan W. Żelazny, prof. UPJPII - kierownik Katedry Patrologii na Wydziale Teologicznym Uniwersytetu Papieskiego Jana Pawła II w Krakowie; e-mail: jan.zelazny@upjp2.edu.pl.
} 
sprzeczności z tradycją Kościoła. Przeciwnicy głównego protagonisty tych zmian, Bar Saumy, metropolity Nisisbis ${ }^{1}$, szukali przyczyn w osobie samego biskupa. Inni, pozostając w jedności z jego następcami, widzieli w tym wynik i dowód śmiałości wizji, jak i woli adaptacji Kościoła Orientalnego do warunków panujących w Imperium Perskim. Jak było naprawdę, pozostaje dziś chyba poza możliwością ustalenia. Niniejszy artykuł jest próbą ukazania samego wydarzenia, jak i jego szerokiego kontekstu inkulturacyjnego.

Sytuacja polityczna, w jakiej rozgrywały się opisane przez nas wydarzenia, to chwila, w której dwa walczące Imperia pozostają w swoistej równowadze. Z jednej strony potęga króla królów, z drugiej strony Imperium opłacające spokój swoich granic. Tak można by w bardzo dużym uproszczeniu zdefiniować realia polityczne tego okresu. Koniec V w. to czas przemian, ale także niepokojów na tle polityczno-religijnym na wschodzie Imperium Rzymskiego. Po wygaśnięciu dynastii teodozjańskiej na wschodzie Imperium i wojnach domowych o charakterze dynastycznym, władza przeszła w ręce cesarza Anastazjusza. Wybór cesarzowej wdowy Adrianny, małżonki poprzedniego cesarza, Zenona, córki cesarza Leona I i matki jego następcy Leona II, okazał się trafny ${ }^{2}$. Razem $z$ tronem przekazała ona swojemu małżonkowi niepokoje religijne, które ucichły po dekrecie cesarza Henotikon, tym niemniej wrzenie trwało. Nierozstrzygnięta kwestia recepcji orzeczeń soboru w Chalcedonie i wykonywane przez zwolenników ortodoksji ukłony względem przedstawicieli monofizytów, stanowiły zarzewie konfliktów. Podjęta w tej atmosferze przez cesarza Zenona decyzja o zamknięciu tak zwanej szkoły Persów w Edessie (489) i jej przeniesienie do Nisibis spowodowała wrzenie wśród zwolenników antiocheńskich rozwiązań ${ }^{3}$.

Tymczasem decyzja ta wzmocniła zwolenników antiocheńskich rozwiązań, podejrzewanych o kryptonestorianizm, obecnych wśród chrześcijan Orientu. Trzeba podkreślić, że ogólne założenia tzw. antiocheńczyków były bliskie chrześcijanom posługującym się językiem aramejskim ${ }^{4}$. Jednocześnie zorganizowana w Nisibis szkoła stała się ośrodkiem promowania pism i myśli takich autorów jak Teodor z Mopsuestii (zwany w tym środowisku ,egzegetą”),

\footnotetext{
${ }^{1}$ Por. S. Gero, Barsauma of Nisibis and the Persian Christianity in the Fifth Century, Louvain 1981.

${ }^{2}$ Więcej informacji jak i bibliografia dotyczącą tego okresu por. K. Twardowska, Cesarzowe bizantyńskie 2 połowy V wieku. Kobiety a władza, Kraków 2009.

${ }^{3} \mathrm{Na}$ temat tzw. szkoły w Nisibiss i jej powstania, por. A. Becker, Fear of God and Beginning of Wisdom. The School of Nisibis and Christian Scholastic Culture in Late Antique Mesopotamia, Philadelphia 2006; tenże, Sources for the study of School of Nisibis, Liverpool 2008.

${ }^{4}$ Podział na dwie szkoły, mające odmienne metody egzegetyczne, przyjmowany w klasycznej literaturze patrystycznej, wydaje się być nieadekwatny, co wykazał M. Simonetti (Między dosłownościq a alegoriq, Kraków 2000). Jak zwraca uwagę w swoim opracowaniu, różnica dotyczyła bardziej schematów teologicznych niż kwestii egzegetycznych. Moim zdaniem zainteresowania Antiocheńczyków są w wielu miejscach zbieżne $\mathrm{z}$ ideami powszechnymi wśród chrześcijan pochodzenia aramejskiego.
} 
Jan Chryzostom czy Nestoriusz. Szanowani w tych kręgach, uznani za strażników ortodoksji, byli jednocześnie autorami podejrzliwie traktowanymi przez zwolenników rozwiązań aleksandryjskich.

$\mathrm{Na}$ spory dogmatyczne nałożyła się także polityka wewnątrzkościelna. Główny protagonista zmian, Bar Sauma, był zwolennikiem wzmocnienia niezależności biskupów. Być może wiązało się to z jego niechęcią do obserwowanej na greckim Wschodzie i łacińskim Zachodzie interwencji biskupów najważniejszych stolic w funkcjonowanie sufraganii. Ten proces centralizacji był widoczny także w Kościele pod panowaniem perskim, gdzie rolę przywódcy odgrywał biskup Seleucji-Ktezyfontu, który jurysdykcyjnie pretendował do bycia przywódcą wszystkich Kościołów Orientalnych. W zasygnalizowanych okolicznościach doszło do konfliktu pomiędzy Bar Saumą a katolikosem Babowajem. W 484 r. na synodzie w Bet Lapath zwyciężył Bar Sauma i formalnie pozbawiono Babowaja godności. Jednocześnie formalnie odrzucono nauczanie monofizytów, de facto aprobując wyznanie nestoriańskie. Od tego czasu Kościół Orientu traktuje się jako Kościół nestoriański, choć to określenie ani historycznie, ani doktrynalnie nie jest słuszne.

W literaturze trwa spór o kulisy tego konfliktu. Nie wiadomo, na ile o jego ostatecznym rozstrzygnięciu przesądził wpływ, jaki miał Bar Sauma na dworze władcy perskiego. Wiemy, że pomimo obrony samego Babowaja i zwołanego przez niego do Seleucji-Ktezyfontu kontr-zgromadzenia biskupów, którzy odrzucili decyzje z Bet Lapath i poparli Babowaja, nie udało się uzyskać poparcia władz, a Babowaj zginął śmiercią męczeńską. Po elekcji nowego katolikosa Mar Akacjusza zawarto prowizoryczne porozumienie, które miało zostać potwierdzone przez kolejne synody 5 . Tak dochodzimy do roku 497 oraz do synodu w Saliq (Seleucja-Ktezyfont), który potwierdził wcześniejsze ustalenia z Saliq (Seleucji-Ktezyfontu) z 486 roku.

2. Ustawodawstwo z Saliq. Pozostawmy na boku kwestie doktrynalne czy też te związane z pozycją biskupów i strukturą Kościoła pod panowaniem perskim. Tym, co nas interesuje, jest kanon 3. z synodu w Saliq - Seleucji z 486. Ojcowie synodalni już na wstępie podali praktyczne powody swoich decyzji:

„teraz i w przyszłości niech żaden biskup nie stwarza przeszkód ani trudności przeciwko małżeństwu w kraju, w którym rządzi, ani w kościele, w którym sprawuje swą posługę".

Podstawowy wzgląd dotyczył usunięcia tego, co mogło stanowić barierę w pozyskiwaniu nowych wiernych:

${ }^{5}$ Szerzej na temat konfliktu zob. W. Baum - D.W. Winkler, The Church of the East: A Concise History, London - New York 2003, 28.

${ }^{6}$ Concilium Seleuciense in Perside (486) can. 3, ŹMT 62 [wyd. syryjsko-polskie, układ i opracowanie A. Baron - H. Pietras, SCL 6, Kraków 2011], 294. 
„Wystarczy zła, jakie uprzednio spadło na nasze diecezje przez cudzołóstwa i rozpustę, których niegodziwość rozlała się i dotarła także do uszu wszystkich pozostających poza [Kościołem], tak iż urosła wobec nas wzgarda i szyderstwa"”.

Innymi słowy, wcześniejsza praktyka, propagująca bezżenność duchownych, nie sprawdziła się. Zamiast przykładu były skandale, dlatego, aby uniknąć zgorszenia, postanowiono podjąć radykalną decyzję zmieniającą diametralnie praktykę ówczesnego Kościoła, obecną nie tylko we wspólnotach orientalnych. Wcześniejsze, rygorystyczne normy, nakazujące propagować bezżenność wśród duchownych, niepozwalające na zawarcie związku małżeńskiego już wyświęconym i nakazujące oddalić żonę w wypadku elekcji na biskupa człowieka żonatego, miały przestać obowiązywać:

„Niech już nikt z nas nie kieruje się taką postawą wobec własnego kleru, czy to wśród wiejskich prezbiterów, czy też podległych sobie synów przymierza"».

Prezentowane ustawodawstwo poszło o wiele dalej i dotyczyło nie tylko kleru. Chodzi o wspomnianą w zakończeniu cytowanego tekstu grupę synów przymierza, wobec której decyzja ta była wręcz rewolucyjna. Zanegowała nie tylko obyczaj, ale wręcz tradycję będącą u początków chrześcijaństwa orientalnego. Kategoria synów / córek przymierza to specyficzna grupa chrześcijan pomiędzy laikami i duchownymi, wywierająca przemożny wpływ na życie tamtejszego Kościoła.

3. Synowie przymierza $\mathbf{i}$ ich rola $\mathbf{w}$ chrześcijaństwie syryjskim. Ta specyficzna instytucja chrześcijaństwa syryjskiego była związana z ideałem świętości obecnym w świecie semickim. Święty, czyli kadosz, oddzielony od świata, wolny od więzów wynikających ze współżycia seksualnego, a więc z definicji żyjący w pełnej czystości rytualnej, takiej, jak ją rozumiano na Bliskim Wschodzie, był swoistym strażnikiem religijnych wartości we wspólnocie wierzących. Aspekt oddzielenia i całkowitego oddania na własność Bogu w każdym wymiarze życia był istotniejszy w tym środowisku niż typowy dla świata grecko-rzymskiego aspekt doskonałości w cnocie, doskonałości moralnej. Na przestrzeni lat synowie i córki przymierza cieszyli się szacunkiem i poważaniem we wspólnocie chrześcijan, będąc przedłużeniem charyzmatycznych świadków i proroków. Ich styl życia, będący pełnym poświęcenia świadectwem wagi przyjętego chrztu, pojętego jako sakrament doskonałości chrześcijańskiej i znak pełni zjednoczenia z Chrystusem ${ }^{9}$, stanowił jednocześnie wyraz specyficznej, semickiej ascezy, rozumianej jako doskonałe pano-

\footnotetext{
${ }^{7}$ Tamże, SCL 6, 294-295.

${ }^{8}$ Tamże, SCL 6, 295.

${ }^{9}$ Por. J. Żelazny, Chrzest - inicjacja czy petnia chrześcijaństwa? Kilka uwag o rozumieniu chrztu w niektórych wspólnotach syryjskich II i III wieku, w: Katechumenat i inicjacja chrześcijańska w Kościele starożytnym, red. F. Drączkowski i inni, Lublin 2011, 49-61.
} 
wanie człowieka nad sobą, a więc sposób na osiągnięcie nie tylko zjednoczenia z Bogiem, ale i pełni wolności.

Tak pojęta instytucja synów i córek przymierza wpisywała się w mentalność ludzi mieszkających na terenie Bliskiego Wschodu, nie różniąc się od innych obecnych w tym środowisku ruchów religijnych, zarówno wewnątrz samego chrześcijaństwa (enkratyci, messalianie), jak i poza chrześcijańskich (manichejczycy). Wszyscy oni podkreślali wagę ascezy i wyrzeczenia, także w dziedzinie seksualnej. Nieodwołalność wyboru, jego wręcz eschatologiczny charakter był jednym z fundamentów idei synów i córek przymierza. Decyzja synodu pozwalająca na wycofanie się, a więc złamanie ślubu złożonego Bogu, była prawdopodobnie szokująca dla wierzących chrześcijan. Nic nie wiadomo o bezpośrednich protestach, ale wydaje się, że brak zgody na taką postawę musiał towarzyszyć decyzjom synodów, gdyż pomimo wsparcia władzy państwowej, trzeba było ponawiać ustalenia, grożąc ekskomuniką tym, którzy sprzeciwiali się nowościom.

4. Obostrzenia. Wydaje się, że jeszcze jedno sformułowanie miało na celu nie tylko publiczną aprobatę dla podjętych decyzji dopuszczających zmianę ślubu i postanowienia dotyczącego wstrzemięźliwości i zawarcia związku małżeńskiego, ale także wychodziło dalej, wyraźnie stwierdzając, że małżeństwo duchownego ma być zawsze otwarte na życie. Między innymi dlatego w dalszej części cytowanego kanonu pojawiło się potępienie dla jakichkolwiek praktyk antykoncepcyjnych:

„jeśli ktoś będąc poprawnie ożenionym zapobiegał owocom małżeństwa, poza naturalną chorobą niepłodności, ma być pozbawiony jedności z Kościołem oraz święceń kapłańskich"10.

Jak widać antykoncepcja była traktowana jako grzech i to grzech zagrożony ekskomuniką i publiczną pokutą. Ale skoro antykoncepcja była zakazana, czyli duchowni mogli posiadać dzieci i spłodzić je w czasie sprawowania funkcji, to starożytny ideał czystości rytualnej został mocno podważony. Zakaz karania ze strony biskupa za posiadanie potomstwa wraz z zakazem antykoncepcji stawiał problem otwartości na życie w małżeństwach duchownych jako istotną kwestię, tym bardziej że zgodnie z obyczajem kościelnym w tamtych czasach zadeklarowana $\mathrm{w}$ powyższym przepisie kara usunięcia ze stanu duchownego odpowiadała karze ekskomuniki dla człowieka świeckiego.

5. Uzasadnienie i konsekwencje podjętych decyzji. Jaka była argumentacja ojców synodalnych z Saliq w latach 486 i 487? Jak sami piszą:

„Nauczanie zaś o tym niech wypływa z nauki świętych ksiąg i z [rozumienia] cudzej słabości" "11.

\footnotetext{
${ }^{10}$ Concilium Seleuciense in Perside (486) can. 3, SCL 6, 296.

${ }^{11}$ Tamże, SCL 6, 295.
} 
Widać jednak wyraźną różnicę interpretacyjną. Do tej pory tekst Pawłowy o tym, co lepsze, a co gorsze, był interpretowany w kontekście wyboru pomiędzy dwiema złymi decyzjami. $Z$ jednej strony grzech rozwiązłości, jaki groził słabemu bratu, z drugiej strony małżeństwo, które powoduje, że człowiek przestaje troszczyć się o sprawy Pana. Argumentacja będąca przyzwoleniem na zawarcie małżeństwa w przypadku, gdy jego brak powodowałby, że brat lub siostra w wierze „płonęliby”, wyraźnie wartościował tę kwestię i nie wystawiał wysokiej oceny małżeństwu. Zreszta, teksty te paradoksalnie stały się tymi, do których często odwoływali się zarówno enkratyci ${ }^{12}$, jak i manichejczycy $^{13}$. Jedni i drudzy odrzucali małżeństwo, jak i rodzenie dzieci, jedni i drudzy spotkali się ze zdecydowaną reakcją Kościoła. Skrajne, wczesnosyryjskie założenie chrzcielne dotyczące zobowiązania przyjmujących ten sakrament do życia $\mathrm{w}$ czystości ${ }^{14}$ nie przetrwało długo i nie mamy późniejszych świadectw tej praktyki poza I i II wiek.

Tymczasem, choć tekst z Pierwszego listu do Koryntian (7, 1-16) był już wcześniej przytaczany $\mathrm{w}$ dyskusji o dopuszczalności małżeństwa, nikt nie kwestionował wyższości wstrzemięźliwości. Wszyscy autorzy kościelni, broniąc świętości związku mężczyzny i kobiety oraz wewnętrznego dobra, jakie towarzyszy zarówno aktowi stworzenia, jak i każdej stworzonej rzeczy, nie omieszkali podkreślić wyższości i piękna innego wyboru. W przytoczonych dokumentach brak tego podkreślenia.

Pojawia się jeszcze jeden, naszym zdaniem istotny wyróżnik. Akta synodalne stwierdzają:

„Przeto każdy z nas wybierze jedno z tych dwóch: albo doskonała wstrzemięźliwość albo regularne małżeństwo, zgodnie z nauką błogosławionego Pawła"15.

Wydaje się, że fundamentalna zmiana w prawodawstwie miała polegać na rezygnacji z ostatecznego charakteru wyboru. Nie jest to wspomniane wprost, i wydaje się, że w dokumentach chodzi formalnie o decyzję dotyczącą wyłącznie kwestii bezpośrednio tego, czy jest możliwe zawarcie małżeństwa przez prezbitera, a więc już wyświęconego. Poświadczałoby to sformułowanie:

„Albowiem legalne małżeństwo i rodzenie dzieci, zarówno przed, jak i po przyjęciu święceń prezbiteratu, jest rzeczą dobrą i poprawną przed Bogiem”"16.

${ }^{12}$ Enkratyci - ruch heretycki na pograniczu gnozy i chrześcijaństwa odrzucający cielesność, a co za tym idzie uważający prokreację za grzech. Por. np. T. Stępień, Chrześcijanie przeciwko filozofi greckiej. Uwagi na temat antyfilozoficznych postaw apologetów, WST 20 (2007) 101-111.

${ }^{13}$ Manicheizm - system religijny powstały w III wieku. Głosił skrajny dualizm z pogardą materii. W procesie wyzwolenia najważniejsze było poznanie. Por. np. W. Eborowicz: Wstęp [do $O$ naturze dobra], w: Św. Augustyn, Dialogi filozoficzne, Kraków 1999², 819-828.

${ }^{14}$ Por. Żelazny, Chrzest - inicjacja, s. 49-61.

${ }^{15}$ Concilium Seleuciense in Perside (486) can. 3, SCL 6, 295.

${ }^{16}$ Tamże. 
Anatematyzmy związane $\mathrm{z}$ tym kanonem odczytane literalnie też sugerują taki kontekst ${ }^{17}$. Jest jednak jedno ale. Fakt zgody na święcenie żonatych już mężczyzn nie był nigdy w tym czasie kwestią kontrowersyjną w całym Kościele powszechnym. Na greckim Wschodzie czy też w semickim Oriencie większość duchownych w małych wspólnotach posiadała rodziny. Prawo mówiące o możliwości wyświęcenia żonatego byłoby tautologią. Novum, a więc zgoda na małżeństwa już wyświęconych, polegało na przyzwoleniu na zmianę decyzji już po święceniach. Milcząco, skoro nie ma żadnych ograniczeń, pozwolenie to jest dane na zawsze, innymi słowy, wyświęcony celibatariusz zawsze może zmienić stan cywilny. Choć wyraźnie zaakcentowana jest zgoda na małżeństwa wdowców, co także stanowiło zmianę tradycji, która od listów pasterskich św. Pawła (na które zresztą powołano się w cytowanym kanonie!) mówiła, że wyświęcany ma być mężem jednej żony ${ }^{18}$, tym niemniej wydaje się, że istotą zaproponowanych rozwiązań było usunięcie w kwestii dotyczącej wstrzemięźliwości ostatecznego charakteru podejmowanych decyzji. Przepis mówi co prawda:

„Ten zaś, który wybrał służbę Chrystusowi w czystości i wyrzeczeniu się wszystkich spraw ziemskich, gdyby popadł w cudzołóstwo i rozpustę wynikającą z przyzwolenia na zawieranie małżeństwa i rodzenie dzieci, powinien otrzymać karę przewidzianą przez kanony: jeśli posiada godność prezbitera, ma być odsunięty od posługi kapłańskiej”'19,

ale padające następnie sformułowanie: ,aż dopełni pokuty odpowiadającej jego wykroczeniu i okaże się godnym przebaczenia"20, sugeruje, że chodzi tu

${ }^{17}$ Por. tamże, SCL 6, 297: „Gdyby zaś ktoś występował przeciwko prawdziwej nauce, albo w swej pysze uważał ją za niesłuszną, gdyby wolał raczej czynić albo nauczać tego, co się łączy z tą obłuda, którą z pomocą łaski Chrystusa zdemaskowaliśmy i pragniemy usunąć z naszego zgromadzenia; i gdyby ktoś nie chciał trzymać się prawdy naszej wiary, zawartej w tej księdze, i nie zachowywał wiernie jednej z tych dwóch dróg, to znaczy doskonałej świętości albo związku zgodnego z prawem, którego ozdobą jest rodzenie dzieci; i gdyby nie przestrzegał reguł wyżej ustanowionych przeciwko tym zwodzicielom, którzy nazywają się ascetami, ale zupełnie nimi nie są; i gdyby ktoś nie potwierdził swego przywiązania do wszystkich tych spraw, w dobrej wierze i w duchu wolności od wszelkiego podstępu, poprzez własną pieczęć i podpis. Co się tyczy biskupa, prezbitera i mnicha: gdyby nauczał rzeczy przeciwnych i nie przyjął wszystkiego, co zostało określone w tym piśmie taki nie będzie miał komunii z nami, wyrzekamy się wszelkiej z nim jedności [59] i zabraniamy mu sprawowania posługi kapłańskiej, której nie wolno mu wykonywać w żadnym ze stopni [święceń] Kościoła. Co się zaś tyczy świeckiego: ma być ukarany i wyklęty. Prawdziwość wszystkiego, co napisano wyżej, potwierdzamy przy pomocy naszych pieczęci i podpisów".

${ }^{18}$ Przykładem niesamowitej egzegezy jest uzasadnienie przyjmujące, że sformułowanie ,jedna żona" oznacza brak zgody na poligamię równoczesną, a więc powtórzenie zakazu rozpusty! Por. tamże, SCL 6, 296-297: ,Jeśli ktoś zawarł prawne małżeństwo a ośmielił się, poza własną żoną, brać sobie inne, albo jeśli ktoś będąc poprawnie ożenionym zapobiegał owocom małżeństwa, poza naturalną chorobą niepłodności, ma być pozbawiony jedności z Kościołem oraz święceń kapłańskich".

${ }^{19}$ Tamże, SCL 6, 296.

${ }^{20}$ Tamże. 
o zdradę małżeńską (karaną ekskomuniką wobec wszystkich wiernych). Natomiast kolejne polecenie dla przełożonego:

„Taki prezbiter, który jeszcze się nie ożenił, a chce zawrzeć legalne małżeństwo i spłodzić prawe dzieci, albo ten, któremu umarła pierwsza żona, a chce wziąc sobie drugą i zachować poprawność związku z tą drugą tak jak z pierwszą, to jego biskup nie ma prawa sprzeciwiać się jego woli’"21,

nie pozostawia wątpliwości. Decyzję dotyczącą życia w celibacie zawsze będzie można zmienić. Taka postawa musiała wywołać dyskusje i kontrowersje, biorąc pod uwagę fakt, że do składanych ślubów podchodzono wówczas o wiele bardziej zasadniczo niż w czasach współczesnych.

6. Ingerencja władzy? Jednak podjęte przez nas zagadnienie dotyczy kwestii na ile przedstawiona powyżej zmiana w praktyce i tradycji Kościoła była akomodacją czy też odpowiedzią na jakiś ferment wewnątrz kościelny, a na ile odpowiedzią na żądania władzy cywilnej i woli części hierarchii na zawarcie trwałego pokoju i wpisanie się w mozaikę religijną ówczesnej Persji. Kluczowe będą dla naszych rozważań słowa rozpoczynające akta kolejnego synodu w Saliq (Seleucji-Ktezyfoncie) z roku 497. Po pierwsze, biskupi zebrani na synodzie wyraźnie stwierdzają $w$ pierwszych słowach i potwierdzają fakt, że ich zgromadzenie odbywa się z woli i na rozkaz króla królów jak i katolikosa:

„W miesiącu tiszri drugiego roku panowania szczęsnego i miłującego po-

kój Zamaspa, króla królów ${ }^{22}$, zgodnie z wolą Bożą, przybyliśmy do miasta

[Seleucja i Ktezyfon] w Bet Armaje, na polecenie króla królów i na wezwanie świętego i miłego Bogu Mar Babaja ${ }^{23}$, biskupa, katolikosa”"24.

Innymi słowy, inicjatywa dotycząca potwierdzenia podjętych wcześniej zmian ma swoje źródło w co najmniej równoległym do decyzji katolikosa rozkazie władcy. Pamiętajmy, nowy katolikos, wybrany po kontrowersji pomiędzy Bar Sauma a Babowajem, był prawdopodobnie „,człowiekiem” Bar

${ }^{21}$ Tamże, SCL 6, 297.

${ }^{22}$ Por. SCL 6, 331, nota B: „Krótkie panowanie Zamaspa z dynastii Sasanidów przypada na lata 496-498. Był synem szachinszacha Peroza (459-484). Wstapił na tron po depozycji jego starszego brata Kauada I (488-496). Według źródeł bizantyńskich (Prokopiusz) powodem usunięcia Kauada I było niezadowolenie perskich możnowładców z jego życzliwości wobec szerzenia się nowej religii. W 498 Zamasp ustąpił z tronu na rzecz powracającego Kauada, który tym razem miał panować aż roku 531". Zob. R.N. Frye, The History of Ancient Iran, München 1984, 150; W.A. Wigram, An Introduction to the History of the Assyrian Church or The Church of the Sassanid Persian Empire, 100-640 A.d., Piscataway 2004, 531.

${ }^{23}$ Babai - Mar Babai I znany jako patriarcha Seleucji-Ktezyfontu, wybrany w 487 r. jako człowiek żonaty rozciagnął postanowienia z Saliq na cały Kościół Asyryjski. Zmarł za panowania następcy Zamaspa, Kauada w czasie walk z Bizantyńczykami, por. Wigram, An Introduction to the History of the Assyrian Church, s. 28-29.

${ }^{24}$ Concilium Seleuciense in Perside (497), Gesta concilii Mār Babaīa, SCL 6, 331. 
Saumy, jemu zawdzięczał wybór, być może także kontakty na dworze. Sam elekt Babaj był przed wyborem człowiekiem świeckim, według późnego świadectwa Bar Hebreusa żonatym, posiadającym dzieci, a więc dojrzałym mężczyzną według kategorii myślenia rozpowszechnionych na Bliskim Wschodzie. Wreszcie - można by powiedzieć posługując się ówczesnymi pojęciami - zwierzchnikiem chrześcijan w krajach Orientu wybrano dojrzałego męża. Ta „świecko-pogańska akceptowalność” była być może jednym z czynników, które doprowadziły do jego elekcji. Nierozstrzygnięte z uwagi na brak źródeł pozostaje kolejne zagadnienie, na ile ta rola czynnika świeckiego, pragnienie postępowania zgodnie z ówczesnymi kategoriami poprawności politycznej, było także na synodzie obecne i decydujące.

Jak świadczy dalsza część dokumentów synodalnych, list zwołujący biskupów na zgromadzenie był wysłany w odpowiedzi na wyrażoną bezpośrednio i oficjalnie wolę władcy. Na samym wstępie zgromadzenia synodalnego patriarcha

„pokazał nam także list synodalny ${ }^{25}$, jaki do niego wystosował miłujący pokój i pełen życzliwości Zamasp, król królów, [z poleceniem,] aby biskupi podlegający jego władzy zgromadzili się wokół niego i aby dokonali reformy tego, co się odnosi do prawnego małżeństwa oraz rodzenia dzieci, wśród duchowieństwa w całym państwie"26.

Władca nie tylko nakazał zebrać biskupów, ale wprost zadecydował o tematyce obrad. Sama decyzja synodu ma mieć odniesienie do prawnego małżeństwa, czyli jak wynikałoby ze sformułowania, ma mieć skutki prawne respektowane na terenie imperium Persji. To zakłada milcząco zmianę charakteru relacji pomiędzy państwem a Kościołem, który staje się jedną z religii „dozwolonych” cieszących się w pewnym zakresie opieką, ale i kontrolą ze strony państwa.

W literaturze uważa się, że postawa władców Persji wobec chrześcijaństwa była zawsze funkcją relacji do Imperium Rzymskiego. W czasie wojny z Rzymem i prowadzonych działań zbrojnych władcy prześladowali ortodoksyjnych chrześcijan, najczęściej będących w dobrych relacjach z panującym we wschodniej części Imperium władcą (do dziś prawosławni chrześcijanie są nazywani na Bliskim Wschodzie melkitami, od słowa melek - król) jednocześnie popierając wszystkie ruchy heterodoksyjne. Tym też tłumaczy się decyzję synodu w Seleucji przyjmującą chrystologię antiocheńską. Taki wybór, zdaniem wielu badaczy, miał przeciąć oskarżenia o współpracę z Rzymem i zdradę interesów perskich - zarzut z jakim chrześcijanie spotykali się dość często.

Zastanawiające, że w decyzjach synodu dyskusja doktrynalna, tak istotna w tej kwestii, nie zajmuje dużo miejsca i jest raczej wspomniana niż kontynuowana. Decyzja kluczowa, która dla wielu chrześcijan z terenów Imperium

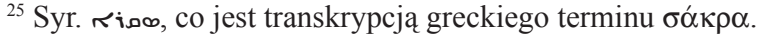

${ }^{26}$ Concilium Seleuciense in Perside (497), Gesta concilii Mār Babaīa, SCL 6, 332.
} 
Rzymskiego zaważyła na odłączeniu orientalnych braci od wspólnoty całego Kościoła, przeszła prawie bez echa. Ojcowie synodu poświęcili najwięcej czasu, jak i zainteresowania zagadnieniu dotyczącemu uspokojenia sytuacji wewnątrzkościelnej oraz kwestii, która wydawać by się mogło bardziej rozpalała emocje, a więc zagadnieniu dopuszczalności małżeństwa wyższych duchownych. Owszem, zagadnienie to było w owym czasie istotne, z uwagi na decyzje korzystającego z poparcia szachinszacha katolikosa Babaja ${ }^{27}$. Sam pozostając w małżeństwie chciał usankcjonować tę sytuację i m.in. dlatego podczas obrad pojawia się expressis verbis stwierdzenie:

„Zezwalamy zatem, aby począwszy od patriarchy aż po najniższego w hierarchii, każdy mógł swobodnie zawrzeć czyste małżeństwo, z jedną kobietą, dla zrodzenia dzieci i dla jego korzyści”28.

Samo zagadnienie wyznania wiary doczekało się krótkiej decyzji ojców synodalnych:

„Zatwierdzamy zatem, ale tylko w tej sprawie, postanowienia zgromadzenia jakie miało miejsce w kraju Bet Huzaje, w 27 roku panowania Peroza, króla królów ${ }^{29} \mathrm{~W}$ mieście Bet Lapat ${ }^{30}$, a także dokument napisany w drugim roku

${ }^{27}$ Tak pisał Bar Hebreus w Kronice syryjskiej (3) o czasie, gdy stolicę objął Babeus (Mar Babai I) i o danej wszystkim duchownym przez nieczystego katolikosa możliwości zawierania małżeństwa: „Po śmierci katolikosa Akacjusza - powiada - zeszli się biskupi i ustanowili sobie katolikosem Babeusa, pewnego człowieka świeckiego, mającego żonę i dzieci, zupełnie pozbawionego umiejętności czytania i znajomości Pism. A on, zebrawszy synod, pod karą suspensy i interdyktu postanowił, żeby wszyscy katolikosowie, jego następcy, brali sobie żony, a także żeby biskup i prezbiter, ilekroć zdarzyłoby się, że ich żony by zmarły, brali sobie drugie. Oczywiście, skoro pozostali chrześcijanie odsunęli ich w wierze, cokolwiek im samym się podobało, aby dogodzić żądzy, to czynili jawnie, bez wstydu i strachu. Gdy zaś Babeus pięć lat sprawował urząd biskupi, zmarł" (tłum. A. Caba, SCL 6, 348). Inne świadectwo dotyczące tej sytuacji daje Eliasz z Damaszku, biskup nestoriański, w napisanym przez niego Nomokanonie: „W drugim roku panowania króla Giamazaby (Zamaspa) katolikos Babeus, który w tymże czasie przewodził Kościołowi, odbył synod metropolitów i biskupów, otrzymawszy od króla możliwość zwołania ich; i przekonał ich, by wszystkim mnichom żyjącym pod ich jurysdykcją zezwolili na legalne małżeństwa i pozwolili płodzić dzieci. Ustanowili przeto, aby katolikosowi i niższym duchownym oraz mnichom zgodnie z Pismem Świętym i Prawem udzielić na przyszłość zgody na branie sobie jednej jedynej żony i zatroszczenie się o dzieci" (tłum. A. Caba, SCL 6, 349).

${ }^{28}$ Concilium Seleuciense in Perside (497), Gesta concilii Mār Babaīa, SCL 6, 332.

${ }^{29}$ Peroz, syn Jezdegerda II, szachinszach Persji w latach 457-484.

${ }^{30}$ Lapat, Beit Lapath, Bet Lapat (484?) tzw. synod nestoriański. Choć akta synodu zorganizowanego przez Bar Saumę w Bet Lapath w 484 r. nie zostały włączone do oficjalnego Synodikonu Kościoła Wschodu, w kwestii dogmatycznej przesądziły o dalszym postrzeganiu Kościoła Wschodu. Po elekcji Akacjusza w 485 r. Bar Sauma szybko podporządkował się nowemu katolikosowi, wyjaśniając swoje stanowisko dogmatyczne i decyzje eklezjalne w sześciu listach, które później dołączono do akt synodalnych, por. J.B. Chabot, Synodikon Orientale, Paris 1902, 525-539. Na temat okoliczności intronizacji Akacjusza, zob. Baum - Winkler, The Church of the East, s. 28. Por. SCL 6, 278, nota B. 
panowania Balasza ${ }^{31}$, w Bet Edraj ${ }^{32}$, za dni Mar Akacjusza, i uzupełniony w kraju Bet Armaje ${ }^{33}$, oraz prawdziwą wiarę, potwierdzoną przez autorytet i naukę świętych ksiąg"34.

Tymczasem na poprzednim synodzie w Seleucji-Ktezyfoncie kwestia wiary była poruszona jako pierwsze zagadnienie, decyzje doktrynalne, z obszernym wyjaśnieniem stanowią treść pierwszego kanonu ogłoszonego przez synod z 486 r. Zmiana jest więc znacząca i naszym zdaniem ukazuje istotne przemieszczenie zainteresowań w życiu Kościoła w kierunku spraw dyscyplinarnych.

Tę tezę potwierdza także inna obserwacja. Dla ojców synodalnych w Seleucji w roku 497 kolejną kwestią istotniejszą od wyznania wiary było zagadnienie dotyczące sporu nieżyjących już Bar Saumy i katolikosa Akacjusza:

„Co do anatematyzmów i zakazów, które od czwartego roku panowania Kauada, aż do drugiego roku obecnego władcy Zamaspa, króla królów, z racji ludzkich i kościelnych były proklamowane tak przez błogosławionego katoliksa Mar Akacjusza i jego współbiskupów przeciwko czcigodnemu Mar Barsamie, biskupowi Nisibis i jego współbiskupom, jak też przez samego Mar Barsaumę i jego współbiskupów przeciwko Mar Akacjuszowi, katolikosowi i jego współbiskupom - obecnie znosimy je i unieważniamy, na mocy słów Chrystusa, który jest ponad wszystkim"35.

Zainteresowanie takie było nieproporcjonalne do wagi sporu - z uwagi na śmierć obu adwersarzy sytuacja już się zdezaktualizowała. Zastanawia dalej czysto praktyczny wymiar pojednania. Nie podjęto żadnych decyzji co do meritum kontrowersji pomiędzy obu hierarchami. W tekście orzeczeń nie ma najmniejszej wzmianki o przyczynie sporu, którą było przecież małżeństwo Bar Saumy z mniszką oraz przeforsowanie przez niego pozwolenia na takie postępowanie dla samego Bar Saumy, jak i innych duchownych. Tekst orzeczenia nic nie mówi o sprzeciwie katolikosów jako wyrazicieli starożytnej tradycji Kościoła. Dokument ujmuje kwestię bardzo enigmatycznie:

„Jednocześnie wszystko to, co było słusznie zakazane, pozostaje zakazane także teraz" ${ }^{36}$.

Innymi słowy, synod potwierdza prawo do zawierania związków małżeńskich przez wyższych duchownych Kościoła i zdejmuje ekskomunikę dla

${ }^{31}$ Szachinszach Balasz (lub Walasz), syn Jezdegerda II, po śmierci swego brata Peroza panował w latach 484-488.

${ }^{32}$ Synod w Bet Edraj w 485 był jedną z prób poszukiwania jedności Kościoła Orientu utraconej na skutek działań Bar Saumy jak i ingerencji władców perskich.

${ }^{33}$ Concilium Seleuciense in Perside (497), Gesta concilii Mār Babaīa, SCL 6, 332.

${ }^{34}$ Tamże.

35 Tamże, SCL 6, 332-333.

36 Tamże, SCL 6, 333. 
tego, który taką postawę potępił. Grożąc klątwą tym, którzy nie przyjmą decyzji ojców synodalnych, zdjęto równocześnie potępienie, jakie za właśnie taką postawę orzeczono względem katolikosa. Nie podjęto się wytłumaczenia tej decyzji (poza enigmatycznym nawiązaniem do słów Chrystusa wzywającego do pokoju) natomiast:

„Wszystkie dokumenty i sentencje spisane przez obie mają być usunięte, i nikomu, na mocy słów Chrystusa, nie wolno przechowywać ich u siebie" ${ }^{37}$.

Warto także dodać, że o wiele więcej miejsca niż dyskusja o kwestiach doktrynalnych, zajmuje opis sporu pomiędzy katolikosem a metropolitą Persji ${ }^{38}$.

Pod koniec wieku V w Kościele Orientalnym pojawiły się rozstrzygnięcia będące w całkowitej sprzeczności z dotychczasową praktyką, jak i tradycją. Zadekretowano nie tylko zgodę na zawieranie związków małżeńskich przez duchownych, ale także i przyzwolenie na rezygnację ze ślubów złożonych Bogu. Działo się to w trudnej sytuacji społeczno-politycznej, gdzie kwestie kościelne, jak i dotyczące relacji z Imperium Perskim splatały się z osobistymi pragnieniami i dylematami uczestników kontrowersji. Na to wszystko nakładała się wola władz, chcących „ujednolicić i upodobnić” wyznawców Chrystusa do innych religii. Ta chęć unifikacji napotkała na dość szeroką grupę osób pragnących pójść z duchem czasów i poprzez akomodację wyjść naprzeciw wyzwaniom ówczesnego świata. Sama próba nie okazała się trwała. W innym kontekście politycznym i wewnątrzkościelnym decyzja została formalnie anulowana (na przełomie V/VI w.). Nie wydaje się, że miała istotny wpływ na życie wspólnot, wiernych raczej starożytnej tradycji i traktujących nowe rozstrzygnięcia z dużą ostrożnością. Nie znamy wielkich hierarchów z okresu bezpośrednio po 497 r., o których mielibyśmy pewne informację dotyczące założonych przez nich rodzin. Innymi słowy, góra zrodziła mysz i wypełniły się słowa proroka „kto poślubia ducha czasu, szybko wdowieje”. Akomodacja, która nie jest przekazem Ewangelii, a tylko dostosowaniem się do wymogów aktualnej politycznej poprawności nie ma szans na trwałe zakorzenienie się w życiu Kościoła.

${ }^{37}$ Tamże.

${ }^{38}$ Por. tamże, SCL 6, 334: „Co się tyczy kościoła w Be[t] Lapat i Jezdada, biskupa Re[w]-Ardaszir, metropolity Persji: dowiedziawszy się od samego Mar katolikosa, że wielokrotnie zapraszał na piśmie i wzywał duchownych z Be[t] Lapat oraz biskupa Jezdada, aby stawili się [na synodzie], oni zaś odmówili”. 


\section{CHRISTIANS IN THE VICINITY OF SHAH. THE PROBLEM OF INCULTURATION \\ ON THE GROUNDS OF THE SYNODAL LEGISLATION OF THE ORIENTAL CHURCH (V-VI CENTURY)}

(Summary)

In the late $5^{\text {th }}$ century, disciplinary practices of the Assyrian Church of the East saw an unprecedented change in the scope of marriages of priests and those serving the God. Synods in Saliq in 486 and 497 agreed not only to consecrate married men but also to allow already consecrated priests and bishops to get married. The synods lifted restrictions on successive bigamy (marriages of widows and widowers) as well. Abstinence as such was limited and priests were allowed to maintain contacts with their wives and have children. This was the key issue for bishops participating in the debate although history remembered the assemblies as proclaiming the Nestorian confession of faith. The matter of adaptation to standards of the Persian society was very pressing, with both resolutions and the course of the debate showing clear intervention of Persian sovereigns. Adopted arrangements remained binding to a greater or lesser extent for over half a century and although they did not introduce any permanent change in the Church discipline, they represent an interesting example of an attempt to adjust the canon law to the social context of the life of Christians in the Persian Empire.

Key words: Oriental Church, synodal legislation, the marriage of bishops, priests and monks, celibacy, Barsaûma.

Słowa kluczowe: Kościół Orientalny, ustawodawstwo synodalne, małżeństwo biskupów, prezbiterów i mnichów, celibat, Barsauma.

\section{BIBLIOGRAFIA}

\section{Źródła}

Concilium Seleuciense in Perside (486), w: Dokumenty synodów od 431-504 roku, [wyd. syryjsko-polskie], układ i oprac. A. Baron - H. Pietras, tłum. R. Zarzeczny, ŹMT 62 = SCL 6, Kraków 2011, 291-299.

Concilium Seleuciense in Perside (497), w: Dokumenty synodów od 431-504 roku, [wyd. syryjsko-polskie], układ i oprac. A. Baron - H. Pietras, tłum. R. Zarzeczny, ŹMT 62 = SCL 6, Kraków 2011, 331-337.

\section{Opracowania}

Baum W. - Winkler D.W., The Church of the East: A Concise History, London - New York 2003.

Becker A., Fear of God and Beginning of Wisdom. The School of Nisibis and Christian Scholastic Culture in Late Antique Mesopotamia, Philadelphia 2006.

BECKER A., Sources for the study of School of Nisibis, Liverpool 2008. 
Снавот J.B., Synodikon Orientale, Paris 1902.

Eborowicz W., Wstęp [do O naturze dobra], w: Św. Augustyn: Dialogi filozoficzne, Kraków $1999^{2}, 819-828$.

FrYe R.N., The History of Ancient Iran, München 1984.

Gero S., Barsauma of Nisibis and the Persian Christianity in the Fifth Century, Louvain 1981.

Simonetti M., Między dosłownościa a alegoria, Kraków 2000.

STĘPIEŃ T., Chrześcijanie przeciwko filozofii greckiej. Uwagi na temat antyfilozoficznych postaw apologetów, WST 20 (2007) 101-111.

Twardowska K., Cesarzowe bizantyńskie 2 połowy $V$ wieku. Kobiety a władza, Kraków 2009.

Wigram W.A., An Introduction to the History of the Assyrian Church or The Church of the Sassanid Persian Empire, 100-640 A.d., Piscataway 2004.

ŻELAZnY J., Chrzest - inicjacja czy petnia chrześcijaństwa? Kilka uwag o rozumieniu chrztu w niektórych wspólnotach syryjskich II i III wieku, w: Katechumenat i inicjacja chrześcijańska w Kościele starożytnym, red. F. Drączkowski i inni, Lublin 2011, 49-61. 